\title{
KONGEMOSE FLINT TECHNOLOGY \\ IN THE EAST BALTIC AREA. SOME EXAMPLES FROM LITHUANIAN STONE AGE SITES
}

\section{TOMAS RIMKUS}

\begin{abstract}
This article presents data on Kongemose culture material which has been found in Lithuania but not yet studied. Based on material from west, east and south Lithuania Stone Age settlements, the aim is to acknowledge the existence of this culture's technology during the Atlantic period in the east Baltic region. The use-wear method was also used for a more detailed analysis. The results of the article contain versions of the emergence and development of rhombus-shaped arrowhead technology in the east Baltic during the Stone Age period.
\end{abstract}

Key words: Kongemose and Nemunas cultures, microlithic technology, Late Mesolithic-Early Neolithic, use-wear, Lithuania.

DOI: http://dx.doi.org/10.15181/ab.v25i0.1831

\section{Introduction}

One of the most characteristic features that distinguish the Mesolithic period in the east Baltic region is microliths. These are small, mostly (but not only) made of flint, and represent geometric-shaped articles, usually used for composite tools. Use-wear and experimental studies confirm that these tools were most often used in hunting (Fischer et al. 1984; Fischer 1989; LammersKeijsers et al. 2014; O’Driscoll, Thompson 2014; Sano, Oba 2015; Skakun et al. 2014; Winiarska-Kabacińska 1993; Yaroshevich et al. 2013; Zhilin 1998). There is also data on the use of microliths for other work (Osipowicz 2014, 421; Rimkus 2016). In south and central European areas, the Russian and Ukrainian steppes, microlithic tools were already in production at the beginning of the Late Palaeolithic, and used by Aurignacian, Gravettian and Magdalenian cultures (Bordes 2006, Fig. 17; Giria, Bradley 1998; Kozłowski 2015; Movius 1968; Sinitsyn 2003). Although the first use of microliths in Lithuanian archaeological material is recorded at the end of the Late Paleolithic in Federmesser and Ahrensburgian culture finds (Šatavičius 2005, 59 ), the real beginning of microlithisation is considered to be the pre-Boreal period. So far, in the absence of a solid chronology of the Mesolithic in Lithuania, these two moments, the beginning of the Holocene and microlithic products, are among the main criteria in Lithuania for identifying the beginning of the Mesolithic (Girininkas 2009, 76; Ostrauskas 1998).

According to the archaeological material, quite a contrasting cultural situation is observed in Lithuania during the Mesolithic. At the beginning of the pre-Boreal, Swiderian culture technology still existed, but Kunda
(Pulli) culture, related to it, appears alongside (Sulgostowska 1999, 87), which already has microlithic implements and the blade pressure technique from oneplatform cores. In the pre-Boreal and Boreal transition, archaeological material increases in the number of different types of microliths, which are treated differently by archaeologists in this region. There are versions of Maglemose, Kudlayevka or the still unidentified existence of post-Ahrensburgian technology in the southern part of Lithuania (Jablonskytè-Rimantienè 1966; Ostrauskas 2002a; Šatavičius 2016, 34), but due to a lack of data and well-stratified settlements, this problem remains debatable (Girininkas 2009, 92; 2011, 79). Nemunas culture is distinguished in the second half of the Mesolithic in Lithuania, whose inventory is characterised by the large use of lanceolates, microburin and handle core technology, and the emergence of various other geometrically shaped microliths and trapezoid arrowheads. It is important to note that there are no large differences in flint material when analysing Early Neolithic settlements and comparing them with the Late Mesolithic. The continuation of the use of the same products, including microliths, is largely evident.

Only recently, when the author of this article began to study the production technique and the use of microliths in northern Europe, did some similarities with southern Scandinavia's Middle Mesolithic (according to the established Mesolithic chronology in Denmark and Sweden) Kongemose culture emerge in Lithuania. In particular, attention was paid to the types of rhombic points that are typical of this culture. Their existence was discovered in seven places. They are located in different regions of Lithuania, so it is worth considering that the phenomenon was much wider in context.

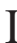

STONE AGE IN NORTHERN EUROPE: CHANGES IN LANDSCAPE, TECHNOLOGIES AND BELIEFS 


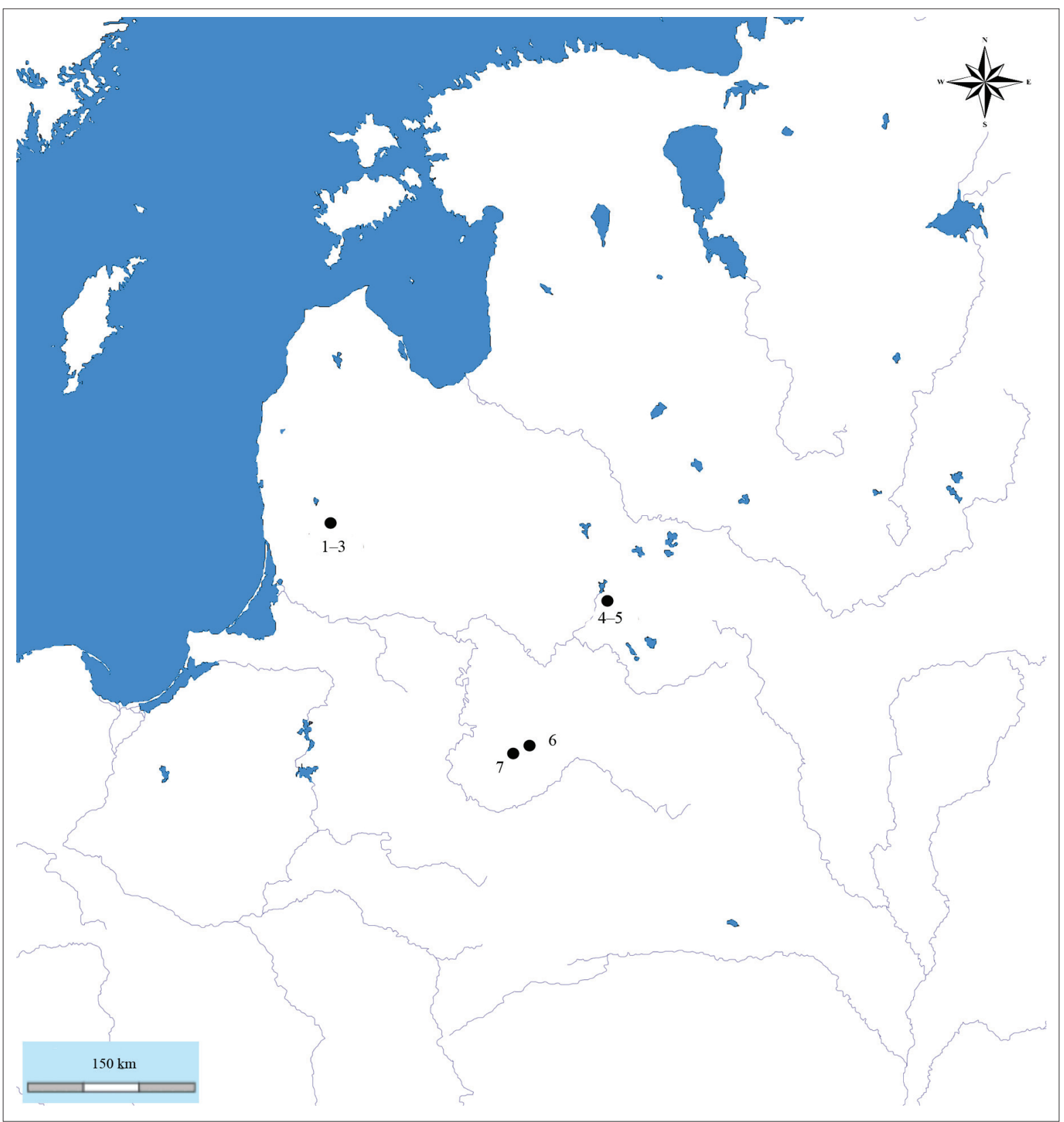

Fig. 1. Map showing the locations of sites mentioned in the text: 1-3 Daktariškè 5, Dreniai and Spiginas grave 1; 4-5 Kretuonas $1 \mathrm{C}$ and Pakretuonè 4; 6 Gribaša 4; 7 Katra 1 (compiled by Tomas Rimkus).

The existence of Kongemose technology also confirms the handle cores which were used for blade pressure technique. In northern Europe, these are the main criteria that distinguish Kongemose culture sites (Blankholm 2008, 112; Larsson 1980, 20).

\section{Material and methods}

For this research, archaeological material was used from the following sites: Daktariške 5, Dreniai, Spiginas grave 1 (Telšiai district), Katra 1, Gribaša 4 (Varèna district), Kretuonas 1C, and Pakretuonè 4 (Švenčioniai distrcit) (Fig. 1). In total, 12 rhomboidshape arrowheads were identified that are characteristic of the technology of Kongemose culture. The archaeological excavations and material from these sites have been published several times (Butrimas 1989, Fig. 2; 1990; 1992; 1998, 122-123; 2012, Fig. 78; 2016a, 8695; Česnys, Butrimas 2009, 3; Girininkas 1990; 2008; Grinevičiūtè, Ostrauskas 2000; Grinevičiūtė 2002; Ostrauskas 1996, 204).

The use-wear method in this study was adapted for the functional analysis of rhomboid points. This research was carried out at the University of Klaipeda, in the laboratory of experimental archaeology and use-wear. An Olympus SZX16 stereoscopic microscope with an attached Olympus DP72 camera was used for the research. With this microscope, the image of an object 
can be increased from seven to 690 times. Pictures of captured traces were processed by Image-pro Express 6.3 software.

\section{The sites}

The Daktariškè 5 settlement (Telšiai district, west Lithuania) was found in 1986, and excavated in the 1987-1990 seasons (Butrimas 2016b, 22). The excavations revealed numerous Neolithic amber, flint, bone, antler and pottery artefacts. Two rhombic points characteristic of Kongemose culture were found in the cultural layer of the settlement (Fig. 2. 1, 2). According to radiocarbon data, the beginning of the Daktariške 5 settlement should be dated to the Early Neolithic: 4468-4246 cal BC and 4360-4250 cal BC (Butrimas 2016b, 23). This is also confirmed by the latest exacavations and AMS dating of the material (Piličiauskas et al. 2017).

The Dreniai Stone Age site (Telšiai district, west Lithuania) was excavated in 1993. After short excavations, it was established that the flint material is in mixed layers and cannot be considered as homogeneous (Ostrauskas et al. 1994, 27). The cultural layer was completely ruined by farming activity. However, some Pulli-type arrowheads show the early occupation of the site. The later part of the site should be related to the use of geometric microliths and one-platform conical cores. The material is not dated by radiocarbon; however, on the basis of technical and morphological flint tool features, the authors of the excavations date the site to the Mesolithic (Ostrauskas et al. 1994). One typical Kongemose technology rhombic point was found in the abundant flint inventory (Fig. 2. 3).

The Gribaša 4 settlement (Varèna district, south Lithuania) was found in 1998, and excavated in 1999 and 2000 (Grinevičiūtè, Ostrauskas 2000). The settlement was on the shores of the former Lake Duba. Archaeological excavations revealed an abundant series of flint and pottery artefacts. The technical features of the material enabled the settlement to be fitted into a long chronology: Final Palaeolithic to Late Neolithic (Grinevičiūtè 2002, 7). Three rhombic arrowheads were found in the settlement's flint inventory (Fig. 2. 4-6).

Excavations in the Katra 1 settlement (Varena district, south Lithuania) were conducted in 1998 and 1999 (Girininkas 2000). The settlement is located on the right bank of the River Katra, on a sandy terrace of limnoglacial origin. Like most Stone Age settlements in the southern part of Lithuania, the Katra 1 settlement is a sandy site with mixed material, and has no clear stratigraphy. The abundant archaeological inventory, as in the Gribaša 4 settlement, enables us to date the site to the Final Paleolithic to Early Bronze Age (Girininkas 2000, 13). One typical rhombic point of Kongemose culture has been found in this place (Fig. 2. 7).

The Kretuonas 1C settlement (Švenčionys district, eastern Lithuania) was intensively excavated from 1987 to 1992 (Girininkas 2012, 28). During five seasons of research, a large area of the settlement was explored, and an enormous amount of pottery, bone, antler and flint objects were collected. According to the available radiocarbon data, the settlement dates back to the very end of the Late Neolithic-Early Bronze Age (Girininkas 2009, 257). During the Stone Age, the Kretuonas Lakeland was inhabited from the final Palaeolithic; therefore, it is not surprising that Kretuonas $1 \mathrm{C}$ holds flint tools which were mixed from earlier habitations. Two such are rhombic arrowheads that resemble Kongemose technology (Fig. 2. 8, 9).

The Pakretuonè 4 settlement (Švenčionys district, east Lithuania) was excavated in 1988, 1992 and 1993 (Girininkas 1990; 1994). This is another Stone Age site near Lake Kretuonas. It was dated according to the typology of tools to the Early/Late Mesolithic to Early Neolithic. Only one Kongemose point was found there (Fig. 2. 10).

Spiginas grave 1 was found in 1985-1986, during the survey of an island in Lake Biržulis called Spiginas (Telšiai district, west Lithuania) (Butrimas 1992, 4). The grave was badly damaged by digging trenches during the Second World War. From the disturbed grave, researchers were able to identify a 35 to 45 -year-old male. Human bones from the grave were dated to 4355-4266 cal BC (Butrimas 2012, 71). According to the author of the excavations, two typical Kongemose points were found near the grave (Fig. 2. 11, 12).

\section{Technology and use-wear}

The author succeeded in finding in Lithuanian museums and scientific literature 12 rhombus-shaped arrowheads in total, which resemble Kongemose culture technology (Fig. 2). All of them are made from blades removed from single-platform cores, often with a bright bluish, reddish or whitish patina. The blades were knapped from light grey and whitish flint nodules, whose natural sources are found in southern and western Lithuania (Baltrūnas et al. 2007). According to the remaining bulbs on the Daktariške 5 and Kretuonas $1 \mathrm{C}$ artefacts, it can be concluded that the blades were removed by pressure technique (Fig. 2. 2, 9). Usually only the middle or lower parts of blades were used for manufacturing arrowheads. One of the items from Spiginas 1 has a retouched bulb, which seems to

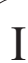

STONE AGE IN NORTHERN EUROPE: CHANGES IN LANDSCAPE, TECHNOLOGIES AND BELIEFS 

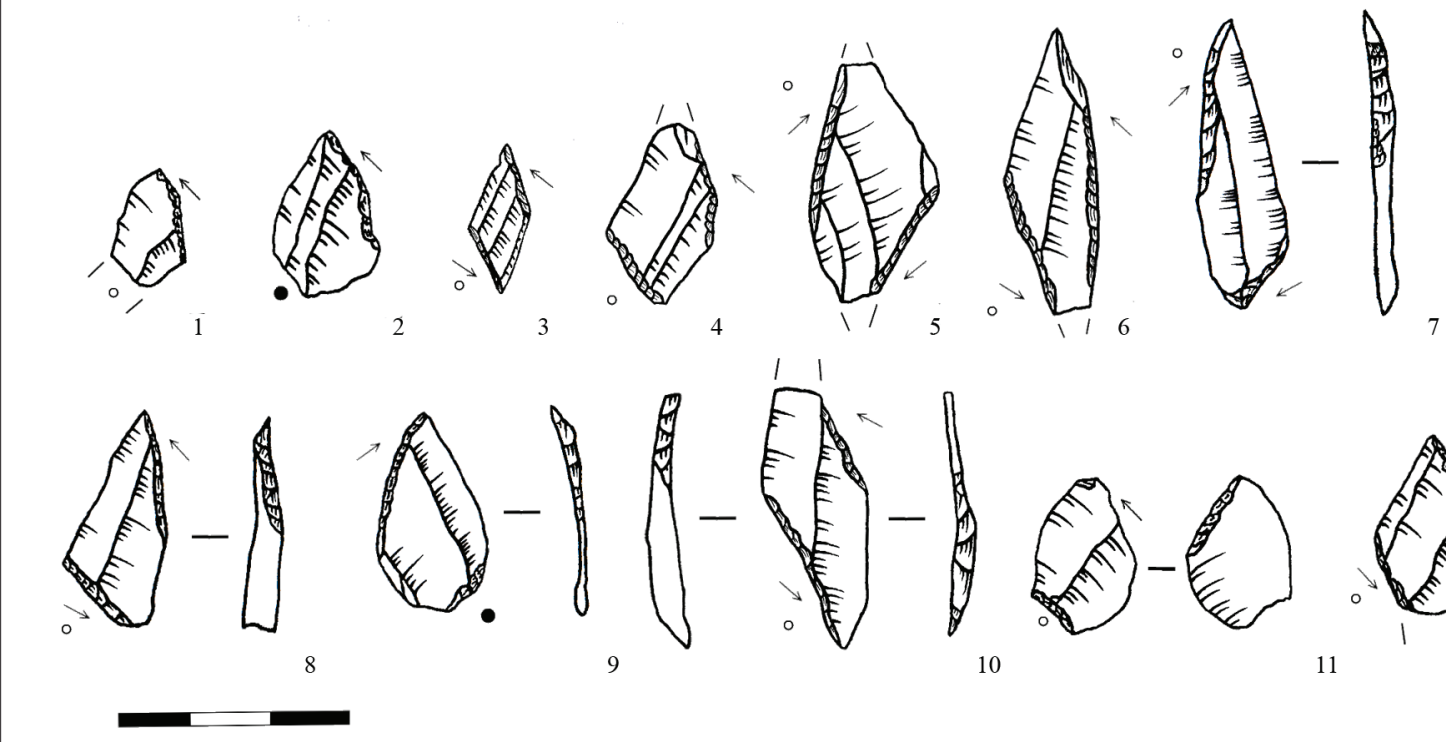

10

11

12

Fig. 2. Rhombus-shaped points from Lithuanian Stone Age sites: 1, 2 Daktariškè 5; 3 Dreniai; 4-6 Gribaša 4; 7 Katra 1; 8, 9 Kretuonas 1C; 10 Pakretuone 4; 11, 12 Spiginas grave 1 (drawing by Tomas Rimkus).

have been an obstacle for hafting the arrowhead. The blades were truncated by microburin or simple breaking techniques. The latter was identified only on one of the items found in the Daktariške 5 settlement (Fig. 2. 2). It cannot be assumed that this article is original in shape. Its proximal end could have been formed by microburin method, but this part could have just been damaged and broken after using the article. Fractures occur on the surfaces of all points as the consequence of use. This allows us to conclude that arrowhead tips formed by microburin technique are quite fragile and break quickly. On the other hand, this blade splitting method gives the much-needed sharpness for the arrowhead.

The sides of the arrowheads are additionally worked by perpendicular retouch. In most cases, microburin spalls were also retouched. Retouch was formed from the reverse to the obverse side for all products, except for the specimen found in Spiginas grave 1, which is retouched from the reverse to the obverse (Fig. 2. 11). It is no wonder that in the literature these points are treated as rhombic or oblique arrowheads, since one side of the artefact is always formed diagonally and acquires a rhombus shape (Brazaitis 1998, 94). The best examples of such shapes are from Dreniai and Spiginas grave 1 .

The tips of the arrowheads were usually formed at the distal ends of the articles. Exceptions are only visible on one of the tools found in the Gribaša 4 and Katra 1 settlements. Perhaps in this particular case, we cannot detect any technical nuance. The functioning parts of the points have always been chosen as the stronger and sharper elements of the tool. These parts were further identified using the use-wear method.

Use-wear analysis was carried out on all the rhombic arrowheads. Working traces were best obtained and captured by increasing the image of an object from 20 to 230 times. The identification of many traces was determined by the flint's raw material, its colour, and the state of preservation of the tools. For example, the analysis of one product found at Daktariške 5 was impossible because the artefact is affected by long-burning (Fig. 2. 1). The intensity of the patina was also a negative factor. On the other hand, during the analysis, the author was able to find technical and functional traces on many articles. First of all, the use of the microburin technique by the use of microscope was confirmed, by which spalls on some tools were removed by retouch (Fig. 3). The investigation of one of the Kretuonas $1 \mathrm{C}$ arrowheads showed multi-direction microscopic striations (Fig. 4). They formed due to the shaping of the proximal end by a retouching tool. It also shows that retouch was formed by a hard material, probably antler. None of the tips of the arrowheads have linear traces formed from strong impacts with obstacles. Only one tool found in the Gribaša 4 settlement can be considered as an exception, but the origin of this trace is not entirely clear. On the other hand, traces of impact have been found in the shape of cleavages or micro-retouch. Such traces were found on almost all the studied points (Fig. 5). Stronger cleavages could have been formed from impact with hard animal tissue (e.g. bone) or missing a target. As a result, the arrowhead could have struck a natural obstacle. The finer traces of micro-retouch probably formed from 


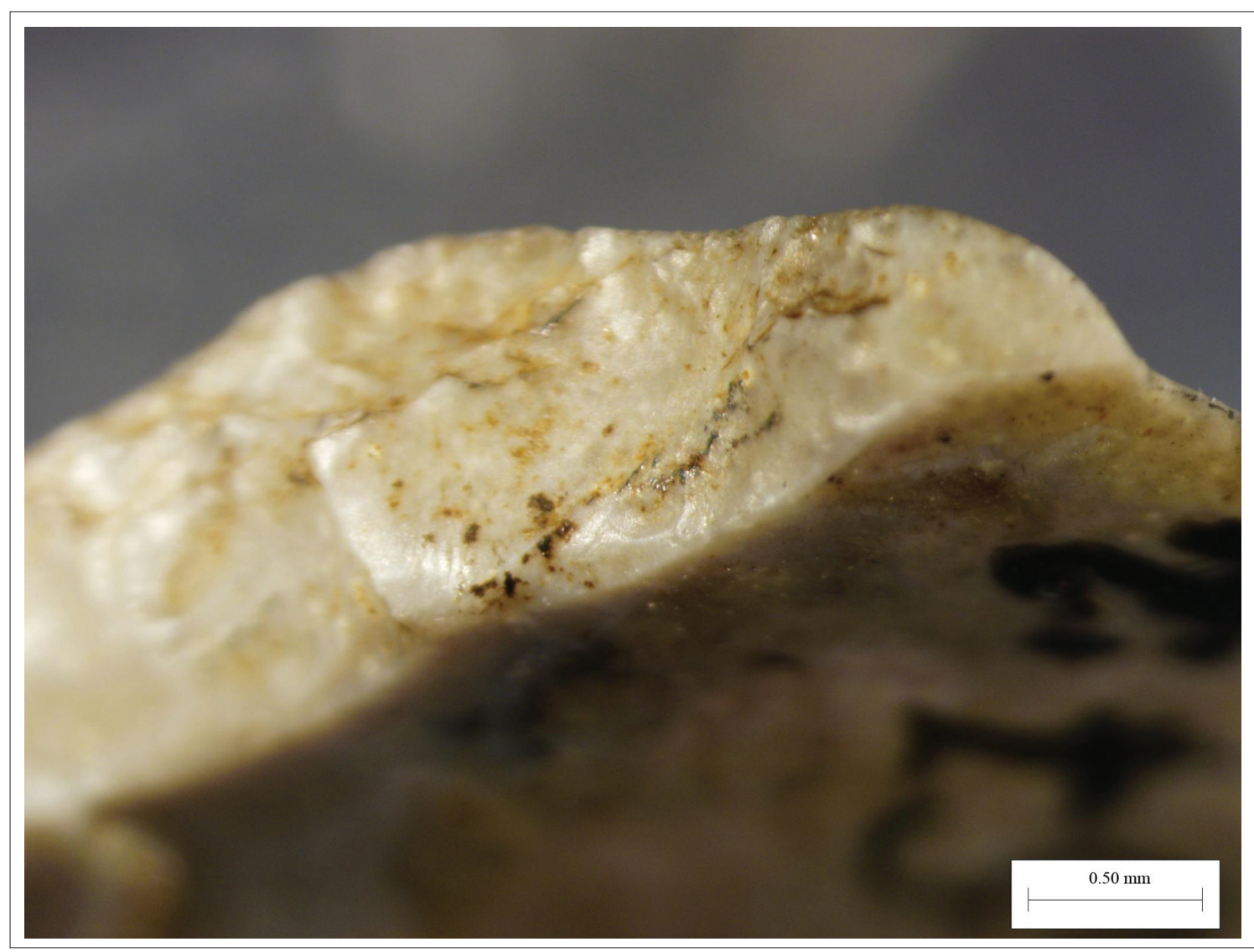

记

Fig. 3. Microburin spall on one of the rhombic points from Spiginas grave 1. Magnification $12.5 \mathrm{x}$ (photograph by Tomas Rimkus).

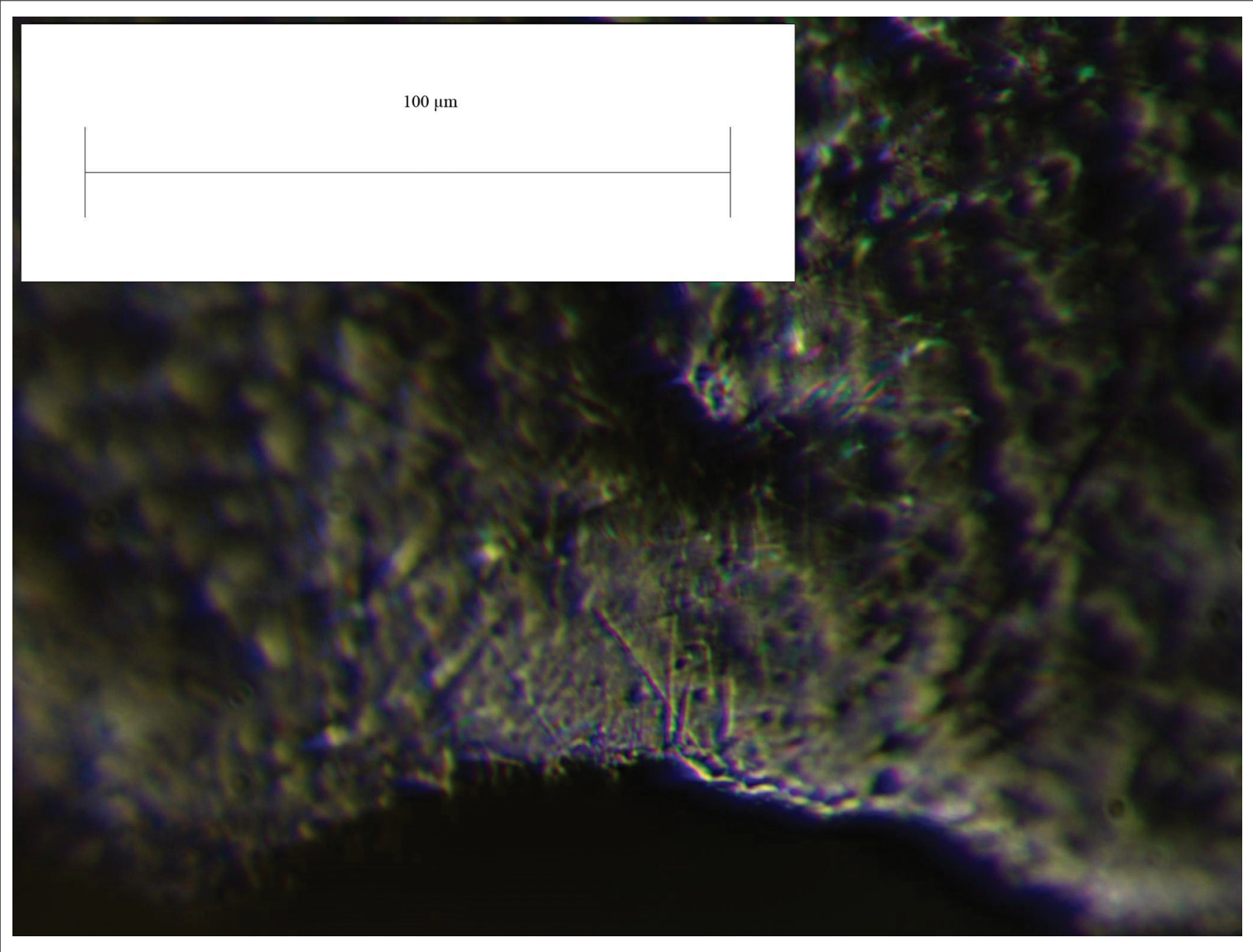

Fig. 4. Striations caused by retoucher in the proximal part of Kretuonas $1 \mathrm{C}$ rhombic point. Magnification 230x (photograph by Tomas Rimkus) 


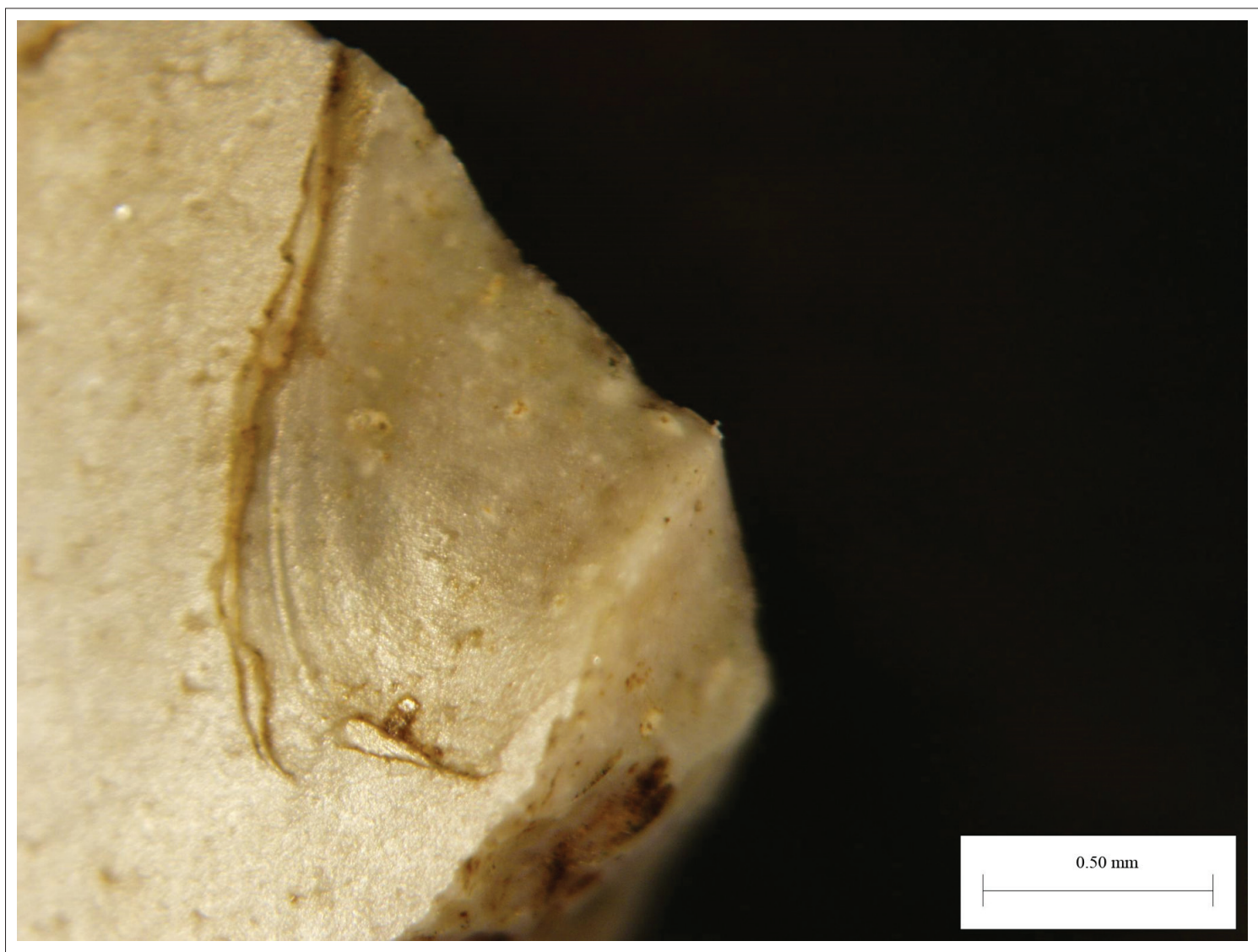

Fig. 5. Use-wear traces from contact with hard material. Arrowhead from Spiginas grave 1. Magnification 16x (photograph by Tomas Rimkus).

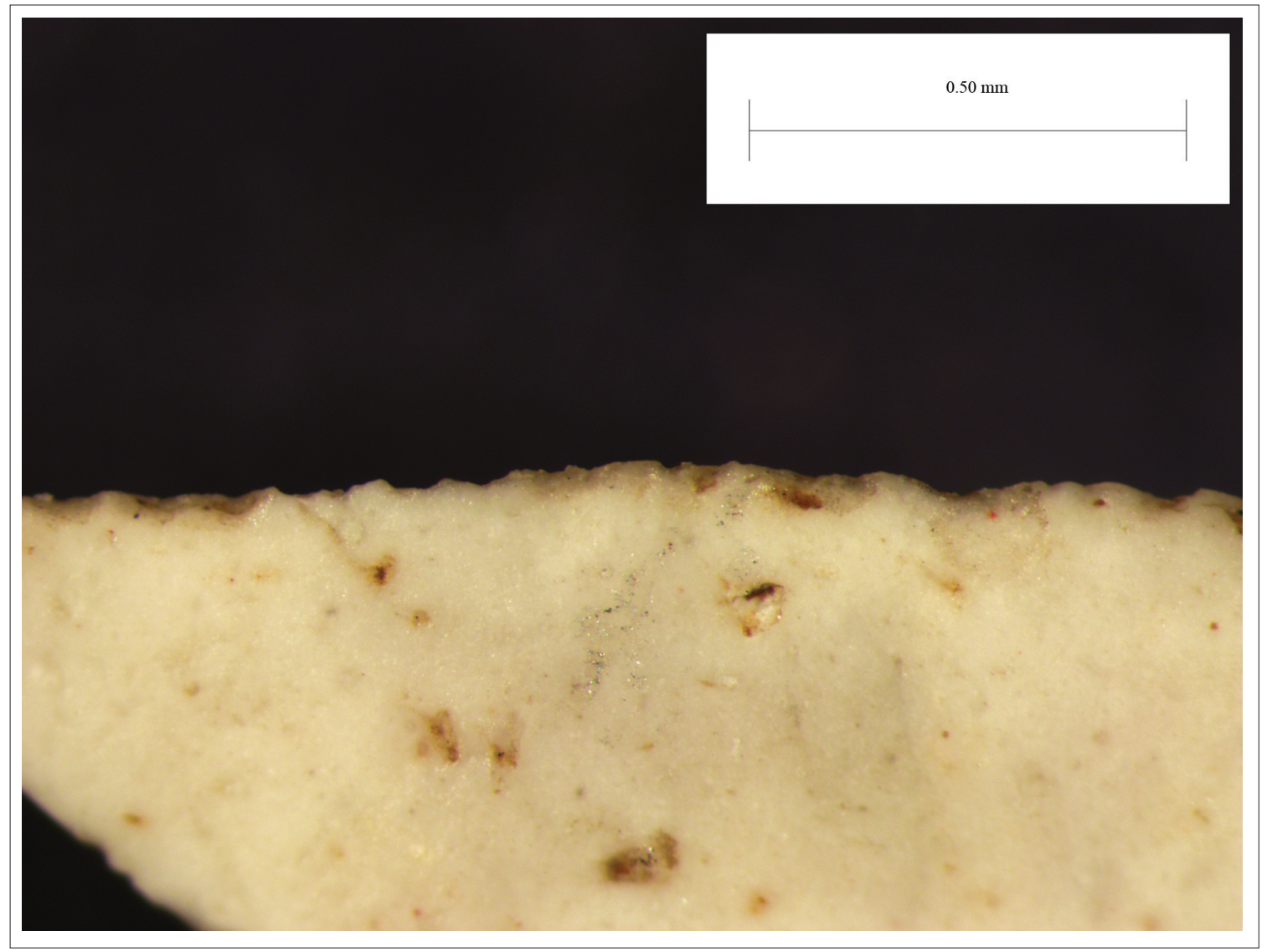

Fig. 6. Use-wear traces similar to knives on the edge of the Dreniai rhombic point. Magnification 32x (photograph by Tomas Rimkus). 


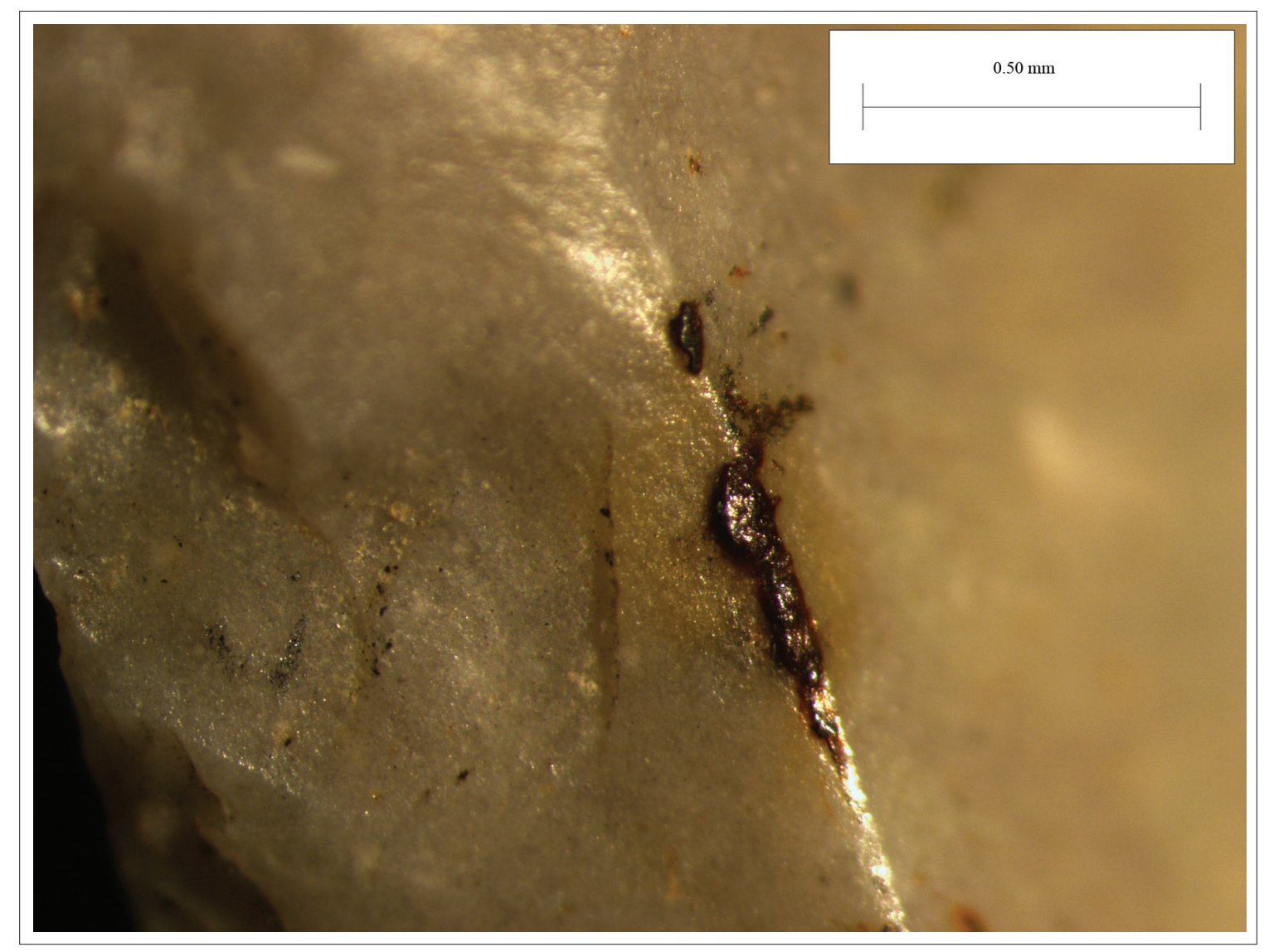

Fig. 7. Pitch residue in the proximal part on one of the points from the Gribaša 4 settlement. Magnification 25x (photograph by Tomas Rimkus).

long-term use and constant contact with animal skin and meat.

In the study of the edges of the obverse and reverse sides, traces of soft material cutting were found. These are often finely 'toothed' traces that have shiny polished features (Fig. 6). They should not immediately be considered as signs of knives. Such deformation of edges arose from constant contact with the game meat. The persistent insertion and removal of an arrowhead from the animal's body formed such 'cutting' traces. It has been experimentally proven that it takes only a few trials for them to appear (Rimkus 2016, 39). Other use-wear traces are related to the technique of hafting the articles into the arrow shafts. Obviously, these microliths were one of the components of the composite tools; therefore, they are supposed to have at least the slightest marks of hafting. They were most commonly found in the proximal parts of the articles and in retouched places. The remains of the hafting was indicated mostly by residues of pitch. It has been found in almost all the lower parts of the products, and in retouched places where the pitch residue is best preserved (Fig. 7). However, only individual laboratory tests can determine the composition of this material (Ulozaite 2013). In addition to the signs associated with the hafting, polished areas were found in the proximal parts of the articles. Some polished areas are of rather uncertain origin. They can apparently be associated with post-depositional factors, or the storage of articles in one place. Microlithic products had the advantage of small size; therefore, they could be manufactured quite quickly, and it was possible to carry dozens of specimens and immediately replace a worn article with a new one if necessary. On the surfaces of the Gribaša 4 and Katra 1 arrowheads, particular polished areas may also be associated with the transport of articles in a leather bag along with other similar products (Fig. 8). This hypothesis has yet to be confirmed by additional research; however, quite similar traces have been recorded in other studies by other use-wear specialists (Pyżewicz, Grużdź 2014). All the technical, morphological and use-wear traces prove that these typical artefacts of Kongemose culture had a definite function as arrowheads.

\section{Discussion}

The first Mesolithic settlements were found in southern Scandinavia in the 19th century. At that time, finds currently known as Kongemose culture did not bear

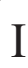

STONE AGE IN NORTHERN EUROPE: CHANGES IN LANDSCAPE, TECHNOLOGIES AND BELIEFS 


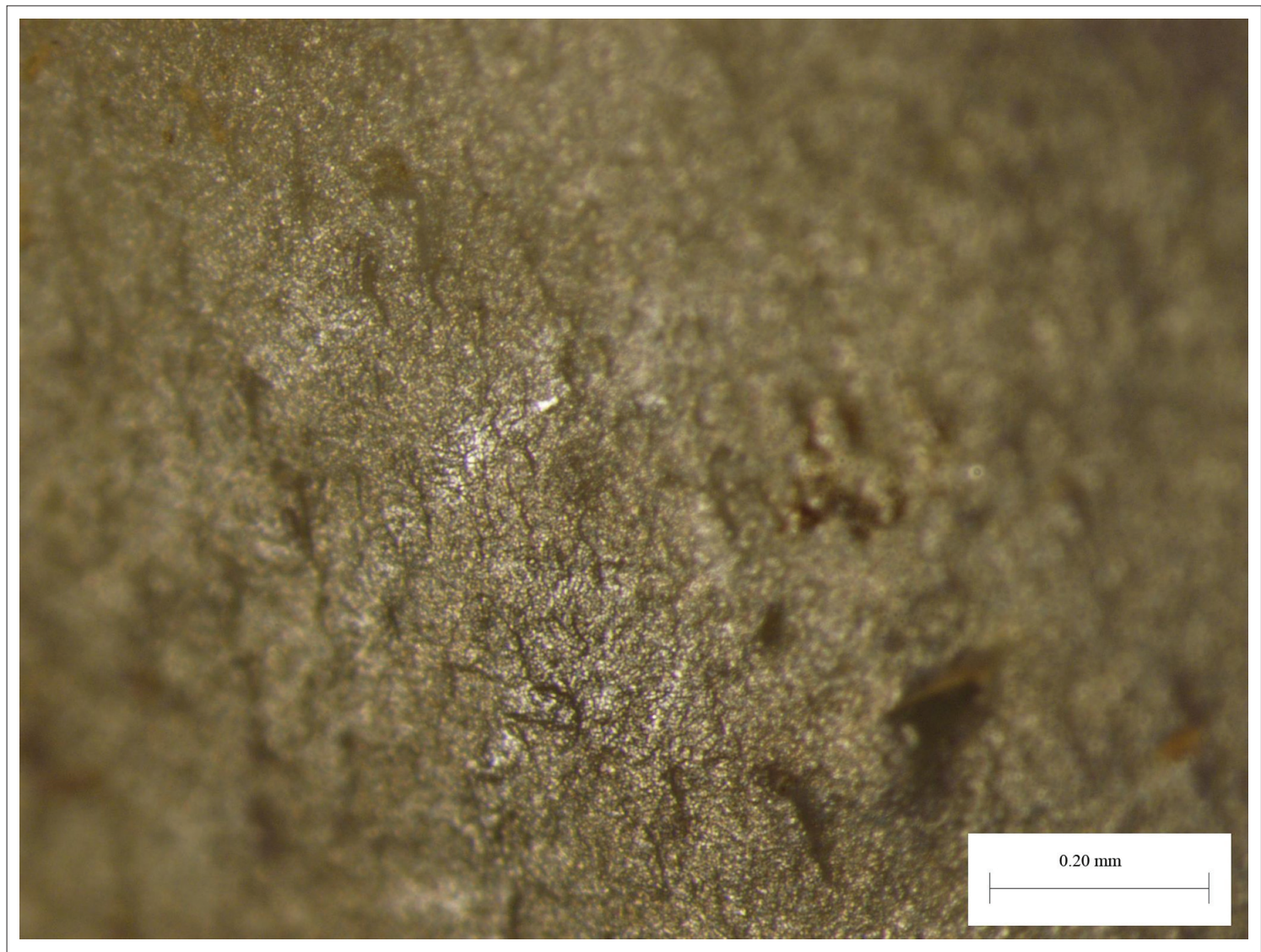

Fig. 8. Post-depositional or possible traces of transport? The rhombic point from the Katra 1 settlement. Magnification 40x (photograph by Tomas Rimkus).

this term. The term Kongemose culture in the archaeology of northern Europe started to be used only from the middle of the 20th century (Brøndsted 1957). The term was applied to a culture which was characterised by handle cores, rhombus and trapezoid arrowpoints (Ballin 2016). Kongemose culture was divided into even more detailed chronological stages on the basis of the chronology and technology of settlements excavated in Zealand (Brinch Petersen 1973). Peter Vang Petersen (1984) identified two phases: Villingebæk and Vedbæk. For the first, rhombus-shaped arrowheads are typical, and in the second stage transverse arrowheads with trapezoid features are distinguished. Later, the earliest stage of Kongemose culture was identified: the Blak phase (Sørensen 1996; 2017, 41). This stage is characterised by the first trapezoid arrowheads. Based on the number of radiocarbon dates and the latest data, Kongemose culture currently fits into the 6550-5400 cal BC period, in southern Scandinavia's Middle Mesolithic period (Larsson 2017b, 19; Sørensen 2017, 36). Later, Kongemose technology arrowheads were gradually changed by the broad trapezes of Ertebølle culture. This concept is characteristic not only in Denmark, but also in the Mesolithic settlements of southern Sweden and northern Germany (Larsson 1990).
Finds of Kongemose culture technology in Lithuania were found in seven Stone Age sites, one of them is also a grave. Geographically, all these places were found in different regions in Lithuania: the west, the south and the east. The lack of radiocarbon data at present does not allow us to make wider conclusions and put these artefacts into chronological frames. Based on the division of Kongemose culture, all these rhombusshaped arrowheads should belong to the Villingebæk phase (6150-5700 cal BC). At present, radiocarbon dates are available only from two places under consideration: Daktariške 5 and Spiginas grave 1. In the Daktariške 5 settlement, the earliest dates go back to almost 4500 cal BC, while Spiginas grave 1 dates back to 4355-4266 cal BC (Butrimas 2016a; 2012; Piličiauskas et al. 2017). At that time in southern Scandinavia, Kongemose culture had already been replaced by the first ceramic communities of Ertebølle culture for several hundred years. It is difficult to evaluate and connect the available dates with these arrowheads. It is very likely that these dates do not reflect the actual chronology of the rhombus-shaped artefacts. The archaeological material in the settlements of Daktariške 5, Dreniai, Gribaša 4, Katra 1 and Pakretuonè 4 are mixed, and have quite a widely spread chronology, while the Spiginas grave was damaged in the Second 
World War; therefore, these tools were not necessarily placed as grave goods. According to radiocarbon records, the Kretuonas $1 \mathrm{C}$ settlement dates back to the end of the Late Neolithic and Early Bronze Age, but it is obvious that this place had been inhabited in much earlier times. At present, the lack of radiological and archaeological data does not allow us to provide solid conclusions about the emergence of these artefacts in the eastern part of the Baltic region. On the other hand, the technology of the Villingebæk phase arrowheads in this area could have been adopted much later, although trapezoid points have apparently been known here since the beginning of the Atlantic period. In the fifth millennium BC, Nemunas culture technology is found in Lithuania, of which the microlithic inventory is almost identical to other Late Mesolithic cultures of the Baltic region (Kozłowski, Kozłowski 1975). It is possible that in the second half of the Atlantic, members of this culture were able to adopt the technology of rhombusshaped arrowheads; however, it is also possible that it developed naturally from lanceolate points. This partly explains the possible late chronology of these products in the eastern part of the Baltic region. The region also contains the commonly used Kongemose culture handle-core technique (Jablonskytè-Rimantienè 1966; Ostrauskas 2002b). This only confirms the use of very similar and sometimes identical flint technology between the Mesolithic and the Early Neolithic technologies of the western and eastern parts of the Baltic Sea.

All technical aspects and use-wear data confirm these tools as being typical of Kongemose culture. It cannot be argued that this culture existed in Lithuania during the Atlantic period. This still has to be confirmed by more data. In the past, it was believed that this culture existed exclusively in southern Scandinavia, but in recent times great studies have been conducted to prove its existence in northern Germany (Hartz 1985). It is likely that it, or at least its technology, could also have existed in other parts of the Baltic region. The author of this article would suggest that the rhombusshaped arrowheads found in Lithuania should only be attributed to Kongemose culture technology. There is currently still a great lack of data to prove the existence of the culture itself. Due to changes in water levels in prehistory, most Kongemose culture settlements are now found submerged in southern Scandinavian sea waters (Larsson 2017a). Current underwater surveys in the Baltic Sea by Lithuanian archaeologists hold much promise to discover the first submerged Mesolithic settlements, which may provide data that is not yet found elsewhere (Žulkus, Girininkas 2014).

\section{Conclusions}

Material from Mesolithic settlements collected over several decades in Lithuania shows that there are rhombus-shaped arrowheads that are typical of Kongemose culture technology. Technical, morphological and use-wear analysis proved that they are homogeneous with Villingebæk phase arrowpoints. The lack of radiocarbon data does not allow us to make more conclusions about the chronology of these items. Radiocarbon dates from Daktariškè 5 and Spiginas grave 1 do not seem to show the true ages of the articles, and should be treated with caution. It might be assumed that during the Atlantic period, Nemunas culture communities managed to take over or develop naturally the technique of arrowheads of such a type.

The Mesolithic in Lithuania is still very poorly studied. There is still a strong lack of chronology and dated organic archaeological material. It is very likely that in the future, new archaeological research on Mesolithic settlements will provide new material associated with Kongemose culture technology. The same can be said about the storerooms of Lithuanian museums, which contain extremely important data, although it needs to be rediscovered.

\section{Abbreviations}

ATL - Archaeological investigations in Lithuania

\section{References}

BALLIN, T.B., 2016. Handle-cores from northern Jutland and regionality in the Danish Mesolithic - is the assumed east-west split as clear-cut as generally perceived? Quartär, 63, 157-168.

BALTRŪNAS, V., KARMAZA, B., KULBICKAS, D., OSTRAUSKAS, T., 2007. Egzotinė titnago bei titnago pakaitalų žaliava akmens ir žalvario amžiu gyvenvietėse. Lietuvos archeologija, 31, 109-122.

BLANKHOLM, H.P., 2008. Southern Scandinavia. In: G., BAILEY, P. SPIKINS, eds. Mesolithic Europe. Cambridge: Cambridge University press, 107-131.

BORDES, J.G., 2006. News from the West: a reevaluation of the classical Aurignacian sequence of the Périgord. Towards the definition of the Aurignacian. Trabalhos de arqueologia, 45, 147-171.

BRAZAITIS, DŽ., 1998. Pyplių piliakalnio papèdès gyvenvietès. Lietuvos archeologija, 15, 87-106.

BRINCH PETERSEN, E., 1973. A survey of the Late Paleolithic and Mesolithic of Denmark. In: S.K., KOZLOWSKI, ed.. The Mesolithic in Europe. Warszawa, 77-127.

BRØNDSTED, J., 1957. Danmarks oldtid, vol. I. København: Gyldendal.

BUTRIMAS, A., 1989. Mesolithic graves from Spiginas, Lithuania. Mesolithic miscellany, 10 (2), 10-11.

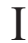

STONE AGE IN NORTHERN EUROPE: CHANGES IN LANDSCAPE, TECHNOLOGIES AND BELIEFS 
BUTRIMAS, A., 1990. Daktariškès 5-osios gyvenvietès tyrinejjimai. ATL 1988 ir 1999 metais, 7-9.

BUTRIMAS, A., 1992. Spigino mezolito kapai. Paminklo tyrinejjimai. Lietuvos archeologija, 8, 4-10.

BUTRIMAS, A., 1998. Biržulio baseino ir Žemaičiu aukštumos akmens amžiaus tyrinejiimu apžvalga. Lietuvos archeologija, 15, 107-131.

BUTRIMAS, A., 2012. Donkalnio ir Spigino mezolito-neolito kapinynai. Seniausi laidojimo paminklai Lietuvoje. Vilnius: Vilniaus dailès akademijos leidykla.

BUTRIMAS, A., 2016a. The Stone Age in West Lithuania. In: G., ZABIELA, Z., BAUBONIS, E., MARCINKEVIČIŪTĖ, eds. A hundred years of archaeological discoveries in Lithuania. Vilnius: Lietuvos archeologijos draugija, 86-95.

BUTRIMAS, A., 2016b. Biržulis. Medžiotojai, žvejai ir senieji žemdirbiai X-II tūkstantmetyje pr. Kr. Gintaras. Vilnius: Vilniaus dailès akademijos leidykla.

ČESNYS, G., BUTRIMAS, A., 2009. Reinventing Mesolithic skulls in Lithuania: Donkalnis and Spiginas sites. Acta medica Lituanica, 16, 1-8.

FISCHER, A., HANSEN, P. V., RASMUSSEN, P., 1984. Macro and micro wear traces on lithic projectile points. Experimental results and prehistoric examples. Journal of Danish archaeology, 3, 19-46.

FISCHER, A., 1989. Hunting with flin-tipped arrows: results and experiences from practical experiments. In: C., BONSALL, ed. The Mesolithic Europe. Edinburgh: John Donald publisher, 29-39.

GIRIA, Y., BRADLEY, B., 1998. Blade technology at Kostenki 1/1, Avdeevo and Zaraysk. In: H.A., AMIRKHANOV, ed. Vostochniy Gravett. Moskva, 191-213.

GIRININKAS, A., 1990. Tyrinèjimai prie Kretuono ežero. ATL 1988 ir 1989 metais, 9-15.

GIRININKAS, A., 1994. Tyrinèjimai Kretuono apyežeryje. ATL 1992 ir 1993 metais, 10-14.

GIRININKAS, A., 2000. Katros 1-oji gyvenvietè. ATL 1998 ir 1999 metais, 12-14.

GIRININKAS, A., 2008. The influence of the environment on the human population around Lake Kretuonas during the Stone Age and the Bronze Age. Archaeologia Baltica, 9, 15-32.

GIRININKAS, A., 2009. Akmens amžius. Lietuvos archeologija, t. 1. Vilnius: Versus aureus.

GIRININKAS, A., 2011. Baltu kultūros ištakos, t. 2. Klaipedda: Klaipèdos universiteto leidykla.

GIRININKAS, A., 2012. The structure of the economy and society in the Early Bronze Age in Lithuania. Archaeologia Baltica, 18, 28-42.

GRINEVIČIŪTĖ, G., 2002. Gribašos 4-oji akmens amžiaus gyvenvietè. Archaeologia Lituana, 3, 5-33.

GRINEVIČIŪTĖ, G., OSTRAUSKAS, T., 2000. Gribašos 4-osios gyvenvietes tyrinèjimai. ATL 1998 ir 1999 metais, 26-29.

HARTZ, S., 1985. Kongemose-kultur in Schleswig-Holstein? Offa, 42, 35-56.

JABLONSKYTĖ-RIMANTIENĖ, R., 1966. Maglemozinė ankstyvojo mezolito stovykla Maksimonyse IV (Varénos r., Merkinès apyl.). $M A D^{`} A, 3$ (22), 43-54.

KOZŁOWSKI, J.K., KOZŁOWSKI, S.K., 1975. Pradzieje Europy. Od XL do IV tysiaclesia p.n.e. Warszawa: Państwowe wydawnictwo naukowe.

LARSSON, L., 1980. Some aspects of the Kongemose culture of southern Sweden. Meddelanden frän Lunds universitets historiska museum 1979-1980, 5-22.
LARSSON, L., 1990. The Mesolithic of southern Scandinavia. Journal of world prehistory, 4 (3), 257-309.

LARSSON, L., 2017a. Submerged settlement in the Öresund, western Scania, southernmost Sweden. In: G.N., BAILEY, J., HARFF, D., SAKELLARIOU, eds. Under the Sea: archaeology and palaeolandscapes of the Continental Shelf. Coastal research library 20. Heidelberg: Springer, $165-175$.

LARSSON, M., 2017b. Life and death in the Mesolithic of Sweden. Oxford: Oxbow.

KOZŁOWSKI, J.K., 2015. The origin of the Gravettian. Quaternary international, 359-360, 3-18.

LAMMERS-KEIJSERS, Y., VERBAAS, A., van GIJN, A., POMSTRA, D., 2014. Arrowheads without traces: not used, perfect hit or excessive hafting material? In: J., MARREIROS, N., BICHO, J.F., GIBAJA, eds. International conference on use-wear analysis: use-wear 2012. Cambridge: Cambridge scholars publishing, 457-465.

MOVIUS, H.L., 1968. Segmented backed bladelets. Quartär, 19, 239-249.

O‘DRISCOLL, C.A., THOMPSON, J.C., 2014. Experimental projectile impact marks on bone: implications for identifying the origins of projectile technology. Journal of archaeological science, 49, 398-413.

OSIPOWICZ, G., 2014. Semi product, waste, tool... Are we sure? Functional aspect of Stone Age morphological flint tools. In: J., MARREIROS, N., BICHO, J.F., GIBAJA, eds. International conference on use-wear analysis: usewear 2012. Cambridge: Cambridge scholars publishing, 398-429.

OSTRAUSKAS, T., BUTRIMAITĖ, D., BUTRIMAS, A., 1994. Akmens amžiaus paminklų žvalgymai Biržulio apyežeryje. ATL 1992 ir 1993 metais, 26-29.

OSTRAUSKAS, T., 1996. Vakarų Lietuvos mezolitas. Lietuvos archeologija, 14, 192-212.

OSTRAUSKAS, T., 1998. Lietuvos mezolito gyvenviečių periodizacija (Daktaro disertacija) Vilnius.

OSTRAUSKAS, T., 2002a. Mezolitinė Kudlajevkos kultūra Lietuvoje. Lietuvos archeologija, 23, 137-162.

OSTRAUSKAS, T., 2002b. Kabeliai 2 Stone Age site. Archaeologia Baltica, 5, 51-82.

PILIČIAUSKAS， G., GAIŽAUSKAS, L., KALINAUSKAS, A., PESECKAS, K., RUTAVIČIUS, J., PILIČIAUSKIENĖ, G., 2017. Daktariškès 5 senovès gyvenvietè. ATL 2016 metais, 41-47.

PYŻEWICZ, K., GRUŻDŹ, W., 2014. Possibilities of identifying transportation and use-wear traces of Mesolithic microliths from the Polish plain. In: J., MARREIROS, N., BICHO, J.F., GIBAJA, eds. International conference on use-wear analysis: use-wear 2012. Cambridge: Cambridge scholars publishing, 479-487.

RIMKUS, T., 2016. Microliths in fisheries? Experimental and use-wear study of composite tools of the Mesolithic South Lithuania. Archeologija un etnogrā $i j a, 29,31-45$.

SANO, K., OBA, M., 2015. Backed point experiments for identifying mechanically-delivered armatures. Journal of archaeological science, 63, 13-23.

SINITSYN, A.A., 2003. A Palaeolithic „Pompeii“ at Kostenki, Russia. Antiquity, 77, 9-14.

SKAKUN, N., ZHILIN, M., TEREKHINA, V., 2014. The history of one arrowhead from a peat bog site in Central Russia (technological and use-wear studies). In: J., MARREIROS, N., BICHO, J.F., GIBAJA, eds. International conference on use-wear analysis: use-wear 2012. Cambridge: Cambridge scholars publishing, 430-440. 
SØRENSEN, S.A., 1996. Kongemosekulturen i Sydskandinavien. Færgegården.

SØRENSEN, S.A., 2017. The Kongemose culture. Copenhagen: University press of southern Denmark.

SUlGOSTOWSKA, Z., 1999. Final Palaeolithic Masovian cycle and Mesolithic Kunda relations. In: S.K., KOZLOWSKI, J., GURBA, L.L., ZALIZNYAK, eds. Tanged points cultures in Europe. Lublin: Marie SkłodowskaCurie University press, 85-92.

ŠATAVIČIUS, E., 2005. Lietuvos vèlyvojo paleolito kultūrų periodizacija. Archaeologia Lituana, 6, 49-82.

ŠATAVIČIUS, E., 2016. The first Palaeolithic inhabitants and the Mesolithic in Lithuanian territory. In: G., ZABIELA, Z., BAUBONIS, E., MARCINKEVIČIŪTĖ, eds. $A$ hundred years of archaeological discoveries in Lithuania. Vilnius: Lietuvos archeologijos draugija, 8-39.

ULOZAITĖ, R., 2013. Archeologiniu radiniu tyrimai infraraudonuju spinduliu (IR) spektrinès analizès metodu. In: A., MERKEVIČIUS, ed. Metodai Lietuvos archeologijoje. Mokslas ir technologijos praeičiai pažinti. Vilnius: Vilniaus universiteto leidykla, 228-248.

VANG PETERSEN, P., 1984. Chronological and regional variation in the Late Mesolithic of eastern Denmark. Journal of Danish archaeology, 3, 7-18.

WINIARSKA-KABACIŃSKA, M., 1993. Analiza funkcjonalna ostrza kościanego krzemiennymi wkładkami z Tłokowa, woj. olsztyńskie. Archeologia Polski, 38 (1), 89-93.

YAROSHEVICH, A., NADEL, D., TSATSKIN, A., 2013. Composite projectiles and hafting technologies at Ohalo II (23 ka, Israel): analyses of impact fractures, morphometric characteristics and adhesive remains on microlithic tools. Journal of archaeological science, 40, 4009-4023.

ZHILIN, M.G., 1998. Technology of the manufacture of Mesolithic bone arrowheads on the Upper Volga. European journal of archaeology, 1 (2), 149-176.

ŽULKUS, V., GIRININKAS, A., 2014. Drowned early Mesolithic landscapes on the Baltic Sea bed in the Lithuanian waters. Journal of environmental sciences and engineering B 3, 274-289.

Received: 4 January 2018; Revised: 20 March 2018, Accepted: 2 April 2018

Tomas Rimkus

Institute of Baltic Region History and Archaeology

Klaipeda University

Herkaus Manto St 84

LT-92294 Klaipėda

Lithuania

E-mail: rimkus74@gmail.com
KONGEMOZÉS KULTÜROS

TITNAGO TECHNOLOGIJA

RYTŲ BALTIJOS REGIONE.

KELETAS PAVYZDŽIŲ

IS LIETUVOS AKMENS

AMŽIAUS GYVENVIEČIŲ

\section{TOMAS RIMKUS}

\section{Santrauka}

Straipsnyje pateikiami duomenys apie Lietuvoje dar detaliau nenagrinètą reiškinị - Kongemozės kultūrą. Išanalizuota 12 rombinių strèlių antgalių iš Daktariškès 5, Drenių, Gribašos 4, Katros 1, Kretuono $1 \mathrm{C}$ ir Pakretuonès 4 akmens amžiaus gyvenviečių bei Spigino 1 kapo (1 pav.). Rasti antgaliai technologiškai visiškai atitinka Pietų Skandinavijoje viduriniu mezolitu datuojamo Kongemozès kultūros Villingeboek etapo dirbinius (2 pav.). Trasologiniai tyrimai rodo, kad antgaliai buvo intensyviai naudojami, ir patvirtina jų, kaip medžioklès įrankių, paskirtị. Ant jų smaigalių randama mikroretušo ir stambesnių išskilimų, kurie rodo, kad dirbiniai kontaktavo su kliūtimis (3-6 pav.). Proksimaliniuose jų galuose ir retušo vietose aptikta įtvèrimo pėdsakų - apsišlifavusių plotų ir dervos liekanų (7, 8 pav.). Kol kas per maža duomenų konkrečioms išvadoms dèl šių dirbinių chronologijos pateikti. Autoriaus teigimu, dirbiniai galejjo būti naudoti atlančio laikotarpiu, o jų technologija buvo perimta arba natūraliai išvystyta Nemuno kultūros atstovų.

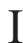

STONE AGE IN NORTHERN EUROPE: CHANGES IN LANDSCAPE, TECHNOLOGIES AND BELIEFS 